\title{
Comparison of Urinalysis and Urine Culture Test in Pregnancy
}

Öz

Amaç: Üriner sistem enfeksiyonları (ÜSE) gebelikte en sık görülen enfeksiyonlardandır. Gebelikte mekanik ve hormonal faktörlerin yol açtığı fizyolojik değişiklikler nedeniyle idrar yolu enfeksiyonu riski artar. Ayrıca mesanenin yetersiz boşalması nedeniyle, idrarın bir kısmı burada kalarak bakteri üremesine zemin hazırlar. Bu çalıșmada amacımı 1. basamak aile hekimlerine başvuran gebelerde ÜSE sıklığını belirlemek ayrıca tam idrar tetkiki (TiT) ve kültür sonuçları arasındaki uyumu saptamaktır.

Yöntem: Laboratuvar bilgi sisteminde 2014 yılı süresince Aile Sağlığı Merkezleri'nden (ASM, birinci basamak sağlık merkezleri) Halk Sağlığı Laboratuvarı'na gönderilen, gebelere ait toplam 1295 TiT ve idrar kültür istemi saptanmıştır. Laboratuvarımıza kabul edilen ve eş zamanlı kültür ile TiT istemi bulunan 1191 örnek çalışmaya alınmıştır. TiT, Labumad Urised (77 Electronica, Budapest, Hungary) cihazında yapılmıştır. Kültür çalıșması konvansiyonel yöntemler ile mikrobiyoloji uzmanı tarafından gerçekleştirilmiştir. Kültür altın standart olarak kabul edilerek TiT-kültür karşıllaştırması gerçekleştirilmiştir.

Bulgular: Kültür analizi sonucu üremesi olan 107 numunenin 41'inde TiT sonucunda pozitif özellik saptanmıstır. Bunlar bakteri/lökosit varlığı ve nitrit pozitifliğidir. Kültürlerde 92 Escherichia coli, sekiz Klebsiella spp., beş Proteus mirabilis ve iki diğer idrar yolu patojeni saptanmıştır. Örneklerin 292'sinde (\% 24.5) kontaminasyon saptandığından örnek tekrarı istenmiş, 768 örnekte ise üreme olmamıstır.

Sonuç: Çalışmamızda TiT'in duyarlılığının düşük özgüllüğ̈̈nün yüksek olduğu görülmüştür. Bu nedenle, gebelerde tek başına idrar yolu enfeksiyonunu dışlamakta TiT yetersiz kalmış ve gebelerde tüm gebelik süreci boyunca mutlaka en az bir kez idrar kültür istemi yapılması yararlı olabilecektir. Ayrıca, kontaminasyon sayılarının yüksek olması, idrar kültür test değerlendirilmesinde preanalitik sürecin önemli bir yer tuttuğunu çalışmamız bir kez daha göstermiştir.

Anahtar kelimeler: gebelik, idrar kültür testi, tam idrar analizi

\section{ABSTRACT}

Objective: Urinary tract infections (UTI) are one of the most commonly diagnosed infections in pregnancy. The risk of urinary tract infection increases due to physiological changes caused by mechanical and hormonal factors. In addition, due to inadequate discharge of the bladder, some of the urine remains and prepares the suitable environment for bacterial growth. The aim of this study was to determine the incidence of UTIs in pregnant women who applied to primary care physicians and to determine the concordance between complete urinalysis and culture results. Method: A total of 1295 urinalysis and urine culture requests of pregnant women submitted to Public Health Laboratory from Family Health Centers (FHC, primary healthcare centers) during 2014 were detected in the Laboratory Information System (LIS). Of these, 1191 accepted specimens with simultaneous urine culture and urinalysis requests were included the study. Urinalyses were done in LabUMat-UriSed (77 Electronica, Budapest, Hungary). Culture was performed with conventional methods by the microbiology specialist. Urinalysis-culture result comparison was made by accepting culture as the gold standard.

Results: Of the 107 culture positive specimens, 41 had positive urinalysis result. Those are presence of bacteria/leucocyte and positive nitrit result. In cultures, 92 Escherichia coli, eight Klebsiella spp., five Proteus mirabilis and two other urinary tract pathogens were detected. Repeat testing was requested in 292 (24.5\%) samples because of contaminationand no growth was detected. No growth was detected in 768 of the specimes.

Conclusion: In our study, low sensitivity and high specifity were detected for urinalysis. Therefore, urinalysis could not rule out UTI and at least one compulsary urine culture submission during the pregnancy period might be beneficial. In addition, high contamination rate showed the importance of preanalytical phase in evaluation of urine culture results once again.

Keywords: pregnancy, urine culture test, urinalysis
Alındığı tarih: 25.01.2019
Kabul tarihi: 22.04 .2019
Yayın tarihi: 30.04 .2019

Esin Avcı

Pamukkale Üniversitesi Tıp Fakültesi Tıbbi Biyokimya Anabilim Dalı Denizli - Türkiye hekimesin@gmail.com ORCID: 0000-0002-9173-0142

N. Çeken 0000-0003-1877-7320 Balıkesir Devlet Hastanesi Tıbbi Mikrobiyoloji Laboratuvarı Balıkesir - Türkiye

*33. ANKEM Akılcı Antibiyotik Kullanımı Kongresi'nde sunulmuştur. Sözlü bildiri No:SB17-45 (2-6 Mayıs 2018, Fethiye) 


\section{Giriş}

Üriner sistem enfeksiyonları (ÜSE), kısa üretra ve üretranın anatomik olarak anal bölgeye yakın olması nedeni ile kadınlarda daha sıklıkla karşımız çıkmaktadır. Gebelikte ortaya çıkan anatomik, fizyolojik ve hormonal değişiklikler normal popülasyona göre enfeksiyon sıklığını arttırmaktadır(2,17). İdrar yolu enfeksiyonları (IYE) asemptomatik bakteriüriden akut piyelonefrite kadar değişebilen çok farklı klinik durumları içermektedir. Asemptomatik bakteriüri hastada semptom olmaksızın idrarda belirgin bakteri olması durumuna denmektedir ${ }^{(7)}$. Gebelerde asemptomatik bakteriüri \% 4-7 oranında görülebilmekte ve semptomatik ÜSE, postpartum ÜSE'ye veya pyelonefrite yol açabilmektedir ${ }^{(18)}$. Bu populasyonda en sık rastlanan suş ise toplum kaynaklı idrar yolu enfeksiyonlarına benzer şekilde Escherichia coli olarak saptanmıştır ${ }^{(10)}$.

Asemptomatik bakteriürinin monitorizasyonu ve takibi, Sağlık Bakanlıkları hedefinde yer alan maternal ve fetal sağlığın geliştirilmesi doğrultusunda önemli bir yer kaplamaktadır. Tanı konulmamış bakteriürinin yan etkileri nedeni ile aile hekimine başvuran gebe kadınlarda mutlaka idrar kültürü yapılmalıdır ${ }^{(13)}$.

Bu hedeften yola çıkarak halk sağlığı laboratuvarımıza gelen gebe idrar örneklerinde ÜSE ön tanısında hızlı bir test olarak kullanılan tam idrar tetkiki (TiT) ile altın standart olmakla birlikte daha uzun zaman alan idrar kültürü sonuçlarının karşılaştırılması amaçlanmıştır.

\section{GEREÇ VE YÖNTEM}

Uşak ili Aile Sağlığı Merkezleri'nde (ASM) çalışan aile hekimlerinin 2014 yılı boyunca ASM'lere başvuran gebeler için yaptıkları TiT ve idrar kültür istemleri Uşak ili Halk Sağlığı Laboratuvarı Laboratuvar Bilgi Sistemi'nden (LBS) retrospektif olarak alınmıştır.

Çalışmaya uygun olmayan numune, yanlış kap kullanımı, kapağın açık kalması, barkotsuz numune, istemin yanlış yapılması/yapılmaması, beklemiş numune çalışmamızda ret nedenleri olarak tanımla- nan preanalitik hatalardır.

Preanalitik hataların azaltılmasına yönelik aile hekimlerine ve de aile sağlığı elemanlarına yılda en az 1 kez eğitim verilmiştir.

\section{Örnek Analizi:}

Tam idrar tetkiki analizleri LabUMat\&UriSed (77 Elektronika Kft, Budapeşte, Macaristan) cihazında gerçekleştirilmiştir. LabUMat kısmı kimyasal analizleri gerçekleştirirken, UriSed kısmında dijital görüntüleme yöntemi ile tam saha görüntüsü elde edilmiştir. тіт analiz ${ }^{(20)}$ sonucuna göre pozitif olarak kabul edilen eşik (cut-off) değerleri aşağıdaki şekildedir: Mikroskopide her alanda >10 lökosit >100 bakteri; kimyasal test sonucunda lökosit pozitifliği, nitrit pozitifliği.

Tam idrar tetkiki ile eş zamanlı gelen gebe idrar örneklerinden idrar kültürü çalışıımıştır. Örnekler \% 5 koyun kanlı agar ve Eosin Methylene Blue (EMB) agar plaklarına ekilmiş ve $37^{\circ} \mathrm{C}^{\prime}$ de $18-24$ saat aerop koşullarda inkübe edilmiştir. İnkübasyon sonunda $10^{3}$ $\mathrm{CFU} / \mathrm{ml}$ ve üzeri üreme saptanan örnekler işleme alınmıştır(7). Konvansiyel yöntemler kullanılarak TSi (Üç şekerli demir agar), indol, metil kırmızısı, VogesProskauer, sitrat ve üre besiyeri kullanılarak tanımlanmışıı ır ${ }^{(1)}$. Üremesi olan grubun antibiyogramı gerçekleştirilmiştir ${ }^{(4,5)}$. Kontaminasyon olarak değerlendirilen örnekler çalışma dışı bırakılmıştır. Kontaminasyon için; karışık bir üreme komplike olmayan poliklinik hastalarında büyük olasıııkla kontaminasyonu işaret edebildiğinden yada düşük seviyelerde $<10^{4} / \mathrm{ml}$ deri ve dış ile iç genital bölgelerde bulunan organizmalar kontaminasyon olarak değerlendirilir(11). Üreyen mikroorganizmalar konvansiyonel yöntemlerle tanımlanmıştır.

\section{İstatistiksel Analiz:}

Kültür altın standart kabul edilerek, idrarın kimyasal ve mikroskopik incelemesi ile karşılaştırıımıştır. Karşılaştırma için TiT sonuçları dört gruba ayrılmıştır.

1. Grup: Lökosit $>10 / \mathrm{hpf}+$ Bakteri $>100 / \mathrm{hpf}+$ Lökosit pozitif + Nitrit pozitif

2. Grup: Lökosit $>10 / \mathrm{hpf}+$ Bakteri $>100 / \mathrm{hpf}+$ 
Nitrit pozitif

3. Grup: Bakteri $>100 /$ hpf + Nitrit pozitif

4. Grup: Çalışmaya alınan dört Tiт bulgusu da negatif

SPSS 15 kullanılarak idrar yolu enfeksiyonu göstergesi olabilecek testlerin tanısal doğruluk parametreleri ve güven aralığı hesaplanmış ve TiT'in kültür istemini öngörmedeki performansı değerlendirilmiştir. Her bir grup için tanısal testlerin performansı ve güven aralıkları hesaplanmıştır.

\section{BULGULAR}

Laboratuvar Bilgi Sisteminden geriye dönük olarak alınan verilere göre; 1295 gebeye ait aynı anda TiT ve/veya idrar kültür analiz istemi gerçekleş-

Tablo 1. Kültür sonuçlarına göre örnek dağılımları ve yüzdesi.

\begin{tabular}{lc}
\hline Kültür Sonuçları & Örnek n (\%) \\
\hline Belirgin bakteriüri (>103 cfu/ml) & $107(9.0)$ \\
Belirgin olmayan bakteriüri $\left(10^{2}-10^{3} \mathrm{cfu} / \mathrm{ml}\right)$ & $24(2.0)$ \\
Kontaminasyon & $292(24)$ \\
Üreme yok & $768(65)$ \\
\hline Toplam & $1181(100)$ \\
\hline
\end{tabular}

Tablo 2. Üreyen mikroorganizmaların sayı ve yüzde dağılımları.

\begin{tabular}{lc}
\hline Üreyen Mikroorganizmalar & $\mathrm{n}(\%)$ \\
\hline Escherichia coli & $92(86.0)$ \\
Proteus spp. & $5(7,5)$ \\
Klebsiella spp. & $8(5.0)$ \\
Pseudomonas spp. & $1(0.75)$ \\
Citrobacter spp. & $1(0.75)$ \\
\hline
\end{tabular}

tirilmiştir. Çalışmaya alınmayan örnek sayısı 104'tür. Bunlardan 19'u numunenin çalışmaya uygun olmaması (yanlış kap, kapak açılması, barkodsuz numune), 68'ü sadece kültür istemi yapılmış olması, 17'si ise sadece Tiт istemi yapılmış olması nedeniyle çalışma dışı bırakılmıştır. Eşzamanlı TiT ve kültür istemi olan ve çalışmaya kabul edilen örnek sayısı 1191'dir. İdrar kültüründe 768 örnekte üreme saptanmamış, 292 örnekte kontaminasyon gözlenmiş, 24 örnekte ise belirgin olmayan üreme kabul edilmiştir $\left(10^{2}-10^{3}\right.$ $\mathrm{CFU} / \mathrm{ml})^{(7)}$ (Tablo 1). Üreyen mikroorganizmalar ve sayıları Tablo 2'de verilmiştir. Gram negatif bakterilerde en sık izole edilen E.coli, Klebsiella spp. ve Proteus spp. izolatlarına en etkili antibiyotikler amikasin, piperasilin-tazobaktam, seftazidim ve kinolon grubu olarak bulunmuştur. Üreme saptanan 107 örneğin belirtilen TiT sonuç gruplarına dağılımı ile Tiт sonucu ile ÜSE tanısının duyarlılığı ve özgüllüğü Tablo 3'te verilmiştir.

\section{TARTIŞMA}

Üriner sistem enfeksiyonlarının gebelik komplikasyonları asemptomatik bakteriüriden ciddi pyelonefrite kadar geniş bir klinik yelpazede gözlenmektedir ${ }^{(9)}$. Schieve ve ark. ${ }^{(15)}$ yaptıkları çalışmalarında gebeliği boyunca ÜSE geçiren kadınların prematüre ve preterm düşük doğum ağırlıklı bebek doğurma riskinin arttığını göstermişlerdir. Bu nedenle aile hekimleri tarafından şikayeti olmayan bir gebede ilk antenatal vizitte (geç ilk veya erken ikinci trimester) ve üçüncü trimesterde tarama amaçlı

Tablo 3. Kültür üreme sonuçlarının Tiт ile karşılaştırılması, karşılaştırma sonuçlarına göre idrar analizinin duyarlılık ve özgüllük oranları.

\begin{tabular}{|c|c|c|c|c|c|c|c|}
\hline \multirow[b]{2}{*}{ Tіт grupları } & \multicolumn{4}{|c|}{ TiT sonuçları } & \multirow[b]{2}{*}{$\begin{array}{c}\text { Kültür pozitif örnek } \\
\text { sayısı }\end{array}$} & \multirow[b]{2}{*}{ Duyarlılık } & \multirow[b]{2}{*}{ Özgüllük } \\
\hline & $\begin{array}{l}\text { Lökosit } \\
\text { (strip) }\end{array}$ & $\begin{array}{l}\text { Nitrit } \\
\text { (strip) }\end{array}$ & $\begin{array}{l}\text { Bakteri >100 } \\
\text { (mikroskopi) }\end{array}$ & $\begin{array}{l}\text { Lökosit >10 } \\
\text { (mikroskopi) }\end{array}$ & & & \\
\hline 1. grup & + & + & + & + & 11 & \%10 & $\% 29$ \\
\hline 2. grup & - & + & + & + & 12 & $\% 21$ & $\% 31$ \\
\hline 3. grup & - & + & + & - & 18 & $\% 38$ & $\% 55$ \\
\hline 4. grup & - & - & - & - & 66 & $\% 38$ & $\% 29$ \\
\hline
\end{tabular}


idrar kültürü çalışılmalı ve yüksek yanlış negatiflik nedeni ile gebe sadece dipstick idrar taraması ile değerlendirilmemelidir ${ }^{(3,8)}$.

Sonuçlar incelendiğinde 66 örnekte üreme olmasına karşın herhangi bir Tiт bulgusu saptanamadığı görülmüştür. Çalışmamız TiT'in kültür yerine geçebilecek bir test olmadığını ${ }^{(3)}$ desteklemiştir. LBS verilerine bakıldığında bu 66 gebeye ait ÜSE ön tanısı olmadığı rutin gebe kontrolü için başvurdukları görülmüş ve bu hastalarda asemptomatik bakteriüri varlığı saptanmıştır. Ülkemizde de asemptomatik bakteriüri sıklığını \% 4-12 arasında bildiren çalışmalar mevcuttur ${ }^{(14)}$.

Gram negatif patojenler için anlamlı olan kültürde saf Gram negatif basil ( $\geq 10^{5} \mathrm{CFU} / \mathrm{ml}$ ) üremesi idrar yollarının akut bakteriyel enfeksiyonları ile ilişkilidir(11). Ancak, gebe kadınlarda ÜSE'nin potansiyel olarak ciddi sekelleri göz önüne alındığında, bakteriyolojik incelemede üreme sınırları $10^{3}$ olarak kabul edilmiştir.

Tam idrar tahlili zaman ve para kaybını önleyen ve hızlı sonuç elde ederek tedaviye erken başlanmasına yarayan bir test iken kültür en az 48 saat sonra sonuçlanan, zahmetli bir testtir. Ancak, çalışmamı TiT'in gebelerdeki idrar yolu enfeksiyonlarını saptamadaki duyarlılığının düşük olduğuna işaret etmiştir. Bulgular kültür pozitifliğini öngördürmede TiT'in duyarlılığının düşük özgüllügünün yüksek olduğunu göstermiştir. Bazı çalışmalar ise bulgularımızın aksi yönünde Tiт'in duyarlılığının yüksek olduğunu göstermişlerdir ${ }^{(5,8,9,16)}$. Ancak çalışmamıza benzer şekilde Mokube ve ark. ${ }^{(13)} 102$ gebede yaptığı çalışmada nitrit pozitifliği duyarlıığını \% 8, lökosit esterazın duyarlılığını \% 20.8 bulmuş, bu iki testin özgüllüklerini daha yüksek saptamışlardır ${ }^{(13)}$. D'souza'nın 100 gebede, idrar kültür testine karşın strip duyarlılığını ortaya koydukları çalışmasında orta akım idrar örneklerinde stripte özellik saptanmaz ise ileri tetkikin gerekli olmadığı, protein ve kan pozitif çıkarsa tedavi verilmeden kültüre örnek gönderilmesi gerektiği ve de nitrit pozitif saptanırsa örneğin kültür için gönderilmesi ama antibiyotik başlanması gereke- bilir önerilerinde bulunmuştur ${ }^{(6)}$. Bizim çalışmamızda stripte nitrit pozitifliği ve mikroskopide bakteri varlığında TiT'in özgüllüğünün en yüksek olduğu görüldüğünden bakteriyolojik testler öncesi proflaktik antibiyotik başlanabileceği görüşüne destek olmaktadır. Sezgin'in ${ }^{(12)} 982$ çocuk hastada gerçekleştirdiği TiT-idrar kültürü çalışmasında nitrit pozitifliği ile kültürde üreme arasındaki uyum $\% 85$ oranında bulunmuş, tanısal performans ölçütlerinin lökosit pozitifliğine göre daha değerli bulgular ortaya koyduğu görülmüştür.

Biz de çalışmamızda her ne kadar TiT in duyarlıIığının düşük olmasına karşın özgüllüğü yüksek olduğundan, antenatal vizitlerde ilk önce TiT çalışılması gerekliliğini maliyet etkinliği açısından önerebiliriz. Tincello 898 gebe örneğinde gerçekleştirdiği Tiт duyarlıık ve özgüllük çalışmasında strip kullanımının yılda tek başına 4000 avro kazanç sağladığını ortaya koymuştur. İdrar örneklerinin kültür çalışmasına gönderilmeden strip ile analizinin önemli olduğunu ortaya koymuşlardır(19).

Çalışmamızda Proteus spp.'nin \% 60 oranında ampisilin ve tazobaktama, Klebsiella spp.'nin \% 28.50 oranında kinolon grubu ajanlara ve E.coli'nin ise \% 17.39 oranında piperasilin tazobaktama dirençli olduğunu gördük. Benzer şekilde Sibi ve ark.'nın ${ }^{(17)}$ 395 gebe idrarında yaptıkları çalışmada en dirençli suşların E.coli ve Klebsiella türlerinin olduğunu, en çok direncin ise eritromisin ve amoksisiline karşı geliştiğini bildirmişlerdir.

Çalışmamızın kısıtlılıkları, örneklerin Aile Sağlığı Merkezleri'nden laboratuvarımıza transfer araçları ile taşınması ve örnek toplama aşamasında preanalitik evrenin kontrol edilememesi idi. Bu süreçlerin kontaminasyon oranını yükselttiğini ve gerçek idrar kültürü üremelerini maskelediğini düşünmekteyiz. Transfer araçlarımızda nakil sürecini çok yakından takip eden "data logger" sıcaklık takip sistemi kurularak uzaktan erişimle örneklerin sıcaklıkları takip edilmiştir. Ayrıca yılda en az bir kez aile hekimlerine ve aile sağ|ı̆̆ı elemanlarına idrar kültür alımı ve de örneklerin taşınması/nakli süreçleri ilgili eğitimler verilmiştir. Tüm bu önlemlere 
rağmen çalışmamızda preanalitik ret oranları kayda değer oranda yüksekti.

Sonuçlarımız, hızlı sonuç veren TiT'in asla kültür yerine kullanılabilecek bir tanısal test olmadığını açıkça göstermektedir. Kültür sonuçları ile TiT arasında mutlak korelasyon beklenmemekle birlikte strip testlerde yanlış pozitiflik yada negatiflik göz önünde bulundurulmalıdır. Ancak maliyet etkinlik açısından strip nitrit pozitifliğinin ve mikroskopide bakteri varlığının gereksiz kültür testleri açısından yönlendirici olabileceğini destekler yönde bulgularımızı da ortaya koyduk. Özellikle ÜSE bir sonucu olarak ciddi komplikasyonlar ile karşı karşıya kalabilecek gebe toplumunda kültürün her trimestirde mutlaka TiT'de pozitif bulgu varlığına bakılmaksızın çalışılması gereklidir.

Çıkar Çatışması: Yazarlar tarafından herhangi bir çıkar çatışması bildirilmemiştir.

Conflict of Interest: No conflict of interest was declared by the authors.

\section{KAYNAKLAR}

1. Bilgehan H. Bölüm: 19 İdrar yolu enfeksiyonlarının mikrobiyolojik incelemesi. "Klinik mikrobiyoloji tanı 4. Baskı" kitabında s 379, Barış Yayınları Fakülteler Kitabevi, İzmir (2004).

2. Chandel LR, Kanga A, Thakur K, et al. Prevalance of pregnancy associated asymptomatic bacteriuria: a study done in a tertiary care hospital. Journal of Obstetrics and Gynaecology of India. 2012;62(5):511-4.

https://doi.org/10.1007/s13224-011-0071-2

3. Cengiz B, Söylemez F. Gebelik ve idrar yolu enfeksiyonları. T Klin J Gynecol Obst. 2001,11

4. Clinical and Laboratory Standards Institute, M100S24, Performance Standards for Antimicrobial Disk Susceptibility Tests; Approved Standard - Eleventh Edition January (2014).

5. Clinical and Laboratory Standards Institute Performance Standards for Antimicrobial Disk Susceptibility Tests; Approved Standard-Eleventh Edition, M02-A11 Vol. 32 No. 1 Replaces M02-A10
Vol. 29 No. 1, January (2012).

6. D'souza Z. Urinary tract infection during pregnancydipstick urinalysis vs. culture and sensitivity. Journal of Obstetrics and Gynaecology. 2004;24(1):22-4. https://doi.org/10.1080/01443610310001620233

7. İnan D. İdrar yolu enfeksiyonları, "Topcu WA, Söyletir G, Doğanay $M$ (eds): Enfeksiyon Hastalıkları ve Mikrobiyolojisi, 4. baskı" kitabında s. 1356, Nobel Tıp Kitabevleri, İstanbul (2017).

8. Kacmaz B, Ozenc C, Altan A, et al. Evaluation of rapid urine screening tests to detect asymptomatic bacteriuria in pregnancy. Jpn J Infect Dis. 2006;59(4):261-3.

9. Khalesi N, Nastaran K, Ali J, Leila A. Evaluation of maternal urinary tract infection as a potential risk factor for neonatal urinary tract infection. J Family Reprod Health 2014;8(2):59-62.

10. Koçoğlu E, Karabay O, Koç İnce N, et al. Toplum kaynaklı üriner sistem infeksiyonlarından izole edilen Escherichia coli suşlarında genişletilmiş spektrumlu beta-laktamaz ve bazı antibiyotiklere direnç sıklığının araştırılması. ANKEM Derg. 2007;21(1):5-9.

11. Lynne SG. Klinik Mikrobiyoloji Yöntemleri El Kitabı, 3. baskı (Çeviri Editörü Ahmet Başustaoğlu, Şinasi Taner Yıldıran) Ankara, Atlas Kitapçııık Tic. Ltd. Şti. (2014).

12. Milletli Sezgin F, Nar R. Evaluation of urinary culture and urinalysis results of pediatric patients prediagnosed with urinary tract infection. Pamukkale Medical Journal. 2017;10(3):242-8. https://doi.org/10.5505/ptd.2017.35002

13. Mokube MN, Atashili J, et al. Bacteriuria amongst pregnant women in the Buea Health District, Cameroon: Prevalence, predictors, antibiotic susceptibility patterns and diagnosis. Plos One. 2013;8(8):e71086. https://doi.org/10.1371/journal.pone.0071086

14. Sarı O. Gebelerde asemptomatik bakteriüri sıklığı. Konuralp Tıp Derg. 2011(1):9-13.

15. Schieve LA, Handler A, Hershow R, et al. Urinary tract infection during pregnancy: Its association with maternal morbidity and perinatal outcome. Am J Public Health. 1994;84(3):405-10. https://doi.org/10.2105/AJPH.84.3.405

16. Schmiemann G, Kniehl E, Gebhardt K, et al. The Diagnosis of urinary tract infection: A systematic review. Dtsch Arztebl Int. 2010;107(21):361-7. https://doi.org/10.3238/arztebl.2010.0361

17. Sibi G, Kumari P, Kabungulundabungi N. Antibiotic sensitivity pattern from pregnant women with uri- 
N. Çeken ve E. Avcı, Tam İdrar Tetkiki ve İdrar Kültürünün Gebe Populasyonunda Karşılaştırılması

nary uract infection in Bangalore. Asian Pacific Journal of Tropical Medicine. 2014;7(Suppl 1): S11620. https://doi.org/10.1016/S1995-7645(14)60216-9

18. Szweda H, Jozwik M. Urinary tract infections during pregnancy, an updated overview. Dev Period Med. 2016;20(4):263-72.
19. Tincello DG, Richmond DH. Evaluation of reagent strips in detecting asymptomatic, bacteriuria in early pregnancy: prospective case series. BMJ. 1998;316(7129):435-7. https://doi.org/10.1136/bmj.316.7129.435

20. Urinalysis Approved Guideline Third Edition Volume 29 Number 4 ISSN 0273-3079. (2009). 